\title{
Ultimate Fighting Championship (UFC) 229: Orientalism vs. Occidentalism
}

\author{
Umer Hussain \\ Texas A\&M University, College Station, USA.
}

\begin{abstract}
Khabib Nurmagomedov versus Conor McGregor Ultimate Fighting Championship (UFC) 229 battle was among the most controversial mixed martial art fights of the past decade. In this study, the author examined how the various popular media outlets from the Eastern and Western world portrayed Khabib Nurmagomedov after UFC 229. The author used Huntington's (1993) clash of civilization thesis by grounding it in the Orientalism and Occidentalism paradigms to examine the phenomenon. Fairclough's $(1989,1995)$ model for critical discourse analysis was employed to investigate the various Western and Eastern popular press and digital media platforms (i.e., newspapers, blogs, and sporting news websites). The author analyzed 57 (Western $n=38$, Eastern $n=19$ ) media reports per the inclusion criteria. The study results unveiled conflicting predispositions present in the Western and Eastern media for Khabib Nurmagomedov. This study contributes to the limited knowledge about how a Muslim man athlete with diverse racial and ethnic backgrounds is seen contrarily in the Western and Eastern media. The author discusses the theoretical implications of the study.
\end{abstract}

Keywords: Clash of civilizations thesis, Orientalism, Occidentalism, Khabib Nurmagomedov, Ultimate Fighting Championship

\section{Introduction}

“The Dagestani champion mauled the brash former 'champ champ' - as McGregor calls himself - taking down the Irishman repeatedly, subjecting him to an absolute skullshattering ground-and-pound that lasted for an excruciating two minutes, before using his terrifying wrestling skills to neutralise McGregor on the ground with a rear naked choke turned neck crank. As Khabib warned before the fight, it was certainly a long night for Conor."

(Turkish Radio and Television Corporation World, 2018)

"Vladimir Putin has expressed his sympathy for Khabib Nurmagomedov after the Russian fighter lost his cool at UFC 229... Nurmagomedov stole headlines around the world after he leapt out of the cage towards his opponent's entourage and incited a massive brawl inside the stadium.......Nevertheless, in a meeting with Nurmagomedov......President Putin congratulated the fighter on his victory."

(Business Insider, 2018a)

The Ultimate Fighting Championship (UFC) 229 fight between Khabib Nurmagomedov and Conor McGregor in 2018 became an international headline (UFC, 2019). The UFC (2019) claimed that the match generated a total of US $\$ 86.4$ million. The event broke previous records of attendance $(20,034)$ and ticket revenue (US\$17,188,894) (UFC, 2019). Conor McGregor, in an interview, claimed that despite losing the match, he made around US\$50 million from the event (ESPN, 2020). According to Dana White, President of the UFC, a rematch between Khabib Nurmagomedov and Conor McGregor would break all the previous records of the mixed martial arts (MMA) industry (Business Insider, 2019). Despite the fight becoming a massive success for the UFC, Khabib Nurmagomedov's after-match 
skirmish with McGregor's ring-side team led to negative criticism in the Western media against the Russian-born Muslim UFC champion.

UFC is an American-based mixed martial arts organization that started its operation in 1993 ('History of UFC,' 2021). The early goal of UFC was to find 'the Ultimate Fighting Champion' via a single-night tournament. During initial UFC fights, there were no clear combative rules. Nevertheless, in 2001, Zuffa LLC. bought UFC, and the new leadership branded the organization events into a highly structured and controlled combat sport. UFC nowadays produces annually more than 40 live events ('History of UFC,' 2021). UFC events are also broadcasted in more than 165 countries, having a viewership of more than 1.1 billion individuals ('History of UFC,' 2021). UFC is also being followed by the highest numbers of millennials compared to various other sporting events ('History of UFC,' 2021). However, despite UFC's growing popularity among the youth, numerous media gurus have questioned UFC's racist and xenophobic media strategy (Boston Globe, 2020).

A plethora of scholarly evidence suggests that the Muslim world is being rendered in the Western media as retrograde and inhumane (Ahmed \& Matthess, 2016; Malcolm et al., 2010; Samie \& Sehlikoglu, 2014). For instance, Malcolm et al. (2010) underscored that after the death of Pakistani national cricket team coach Bob Woolmer (a British National), mainstream media painted the Muslim world as unruly, emotional, bizarre, and regressive. Similarly, Ahmed and Matthess (2016) collected 345 scholarly studies after the 9/11 terrorist attacks regarding Muslims' representation in the popular press; they found out that journalistic reporting towards Muslims has a particular kind of racial tilt.

On the other hand, various Muslim media outlets portray the Western world as Islamophobic, Satanist, shameless animals, and racist (Dębnicki, 2016; Gentzkow \& Shapiro, 2004). For example, Dębnicki (2016) conducted a critical analysis of the Islamic Republic of Pakistan's print media. The author unearths that media groups influenced by the rightwing jihadi groups in Pakistan try to develop an anti-West narrative to promulgate conservative Islamic ideology and buttress their political control on the illiterate public. However, there remains a paucity of sociology of sports scholarship about how Muslim men athletes who have a robust Islamic identity/ideology with non-Western ethnicity are portrayed in the Western and Eastern media outlets (i.e., newspapers, blogs, and sporting news websites).

The purpose of this study was to examine how various Eastern and Western popular media platforms (i.e., newspapers, blogs, and sporting news websites) portrayed Khabib Nurmagomedov after his famous clash with Conor McGregor in the UFC pay-per-view fight. To understand the phenomenon, the clash of civilization thesis (Huntington, 1993) was employed by grounding the phenomenon into the Orientalism (Said, 1978) and Occidentalism (Buruma \& Margalit, 2005; Gill, 2004) paradigms. I argue that sporting contexts can offer a means for various ideological beliefs to publicize systematic racism and xenophobia. The propagation of bigotry and rage towards religious beliefs can lead to further hate towards different communities (i.e., the Muslim and Western world) and indicate racism lying in many societies' cultural fabric (Feagin, 2001; Feagin \& Ducey, 2017). This study adds to the clash of civilizations thesis in the sporting context. The study also provides a holistic view of how one sporting phenomenon is seen inversely in the Eastern and Western media. Overall, this study provides an answer to a research question about how the various Eastern and Western media platforms (i.e., newspapers, blogs, and sporting news websites) portrayed Khabib Nurmagomedov after his UFC 229 clash with Conor McGregor.

Research Question (RQ): How Khabib Nurmagomedov was portrayed by the various Western and Eastern media platforms (i.e., newspapers, blogs, and sporting news websites) after his clash with Conor McGregor at UFC 229? 


\section{Theoretical Framework: The Clash of Civilizations Thesis}

In international relations, political science, and sociology literature, one of the most debated theses of the 21st century presented by Huntington $(1993,1996)$ remains the clash of civilizations (Haynes, 2019). The basic proposition of the clash of civilizations thesis is that the fundamental source of conflict in the new world will not be based on ideologically driven economics (i.e., Communism vs. Capitalism) but will be based on cultural differences (Huntington, 1993, 1996). Further, Haynes (2019) argued that the clash of civilizations could be implicit or explicit, such as conventional warfare or conflict in various social activities.

Scholars have widely employed the clash of civilizations thesis to understand the Western world's bias against Muslims in the form of Islamophobia (Haynes 2019; Vorlander et al., 2018). According to Considine (2017), Islamophobia is a type of racial prejudice deeply rooted in the cultural fabric of the Western world. In comparison, the abomination towards the Western world in the Muslim community can be observed through increased terrorism and extremism against Western civilization. Further, outrage in the Muslim world concerning the West could be understood through Huntington's (1993, 1996) explanation about cultural differences could be the cause of implicit and explicit bias.

Huntington $(1993,1996)$ established his arguments by first dividing the world into eight civilizations: Sinic, Japanese, Hindu, Islamic, Orthodox, Western, Latin American, and African. Next, Huntington $(1993,1996)$ unveiled how the balance of power historically has shifted across various civilizations. The scholar underscored that the decline of various civilizations was not linear but dependent upon numerous factors. Huntington (1993, 1996) also highlighted that after the Cold War, the world order had shifted again towards Western civilization. Finally, Huntington $(1993,1996)$ gave the clash of civilizations thesis by unfolding differences between Western and other civilizations. Huntington (1993, 1996) emphasized that in-depth historical friction exists between the Muslim and Western worlds. Thereby, a vital clash would happen between the Muslim world and Western civilization. Fundamentally, Huntington (1993, 1996) developed his thesis based on Lewis' (1990) work about deciphering the roots of Muslims' rage towards the Western world. Huntington $(1993,1996)$ highlighted that the unsatisfied and unemployed Muslim youth and the Western world leaders' attempt to universalize Muslim values had generated intense resentment in the Muslim world. Lastly, Haynes (2019) argued that the clash of civilization between the Muslim world and the West could be observed via social activities (e.g., sports).

\subsection{Sociology of Sports Scholarship and Clash of Civilization Thesis}

Despite scholars trying to study the Muslim world through several sociological and socio-psychological frameworks (Hussain \& Cunningham, 2020; Malcolm et al., 2010; Nakamura, 2002; Ratna \& Samie, 2017; Samie, 2017), there is a lack of scholarship about the clash of civilizations thesis as a framework to understand the Islamophobia, ethnocentrism, eurocentrism, and the prejudice of the Muslim world towards the West in sports. Nevertheless, as sports are a social institution (Bourdieu, 1978), they provide an opportunity to test the clash of civilizations thesis in a competitive environment (Dyreson, 2012). For instance, the 1998 FIFA soccer world cup encounter between the USA and Iran is a classic example of the clash between the West and the Muslim world, not only in the sporting arena but also across the media and public. For example, Billingham (2014) argued that the USA versus Iran in the 1998 soccer FIFA world cup was the most politically charged sporting encounter in the last century.

Dyreson (2010) also underscored that the 2008 Beijing Olympics depicted a clash of civilization between American Capitalism and Chinese Confucian culture. Many Chinese believed that the Olympics is a Western-oriented phenomenon, and Chinese athletes winning the medal were considered a win against American imperialism. Likewise, Sen (2015) 
argued that cricket became a prominent sport in the Indian sub-continent and the Caribbean in the early 20th century because it offered a means to the colonized countries to challenge the British hegemony. Additionally, Pakistan and India cricket matches are seen as a religious war by the people of the two nations (Bandyopadhyay, 2007). Thus, sporting events can provide a means to understand the clash between various cultures.

Even though the clash of civilizations thesis remains a fundamental framework to study international relations in the 21st century, especially the Muslim community (Haynes, 2017, 2019), sport sociologists have not widely employed this framework to understand conflicts between cultures, especially in international sports and media communications scholarship. Ratna and Samie (2017) accentuated that sports scholarship is rooted in ethnocentrism and eurocentrism. They also claimed that numerous scholars try to depict the Muslim world as pejorative, inhumane, emotional, and secondary compared to the Western world. However, there is a paucity of sport sociology scholarship about Muslim men athletes' portrayal in Western popular media platforms (i.e., newspapers, blogs, and sporting news websites) in comparison with the Eastern media outlets (i.e., newspapers, blogs, and sporting news websites). Moreover, due to a Western essentialist world-view dominating the broader sport management discourse (Newman, 2014), Muslim athletes are only seen through the lens of religion, with little to no research done on broader intersections, such as nationality, ethnicity, gender, Orientalism, and nature of sports shaping Muslim athletes' perception in the West through the popular media. In addition, there is a lack of scholarship about how the various Eastern media outlets (i.e., newspapers, blogs, and sporting news websites) are portraying Muslim athletes' success over non-Muslim athletes. Therefore, this study contributes to the various gaps in the scholarship.

\subsection{Criticism on Clash of Civilization Thesis}

According to Haynes (2019), Huntington's (1993) clash of civilizations thesis has been challenged by numerous scholars and reinforced by various right-wing populist political leaders. For instance, Noam Chomsky criticized the clash of civilizations as a new proposition developed to propagate warfare and division among the nations (Shahi, 2017). However, Haynes (2019) argued that numerous world leaders are influenced by the clash of civilizations thesis implicitly and make Islamophobic decisions regarding trade, human rights, and immigration. For instance, due to recent unrest in the Middle East and African countries, nearly 35000 individuals have died while trying to escape in European countries (National Public Radio, 2018). Further, the ban on Hijab in various European countries and the movement against Hijab depicts the implicit bias against the Muslim world in Western societies (Harkness, 2019). On the other hand, Muslim leaders' explicit hate in their political speeches is reported somewhat daily by popular media (e.g., newspapers, blogs, and sporting news websites). Nevertheless, this implicit bias has not been studied in the sport management scholarship regarding the portrayal of athletes in the Western and Eastern media (e.g., newspapers, blogs, and sporting news websites).

\section{Orientalism versus Occidentalism: The Clash of Civilization Thesis}

In the extant scholarship, there are two theoretical approaches (Orientalism and Occidentalism), which have profoundly influenced the body of knowledge about the Muslim World (Buruma and Margalit, 2005; Gill, 2004; Venn, 2000). First, the notion of Orientalism stems from Said's (1978) seminal work on how many Western scholars perceive the Eastern world. Said (1978) underscored that some Western scholars generalize the Eastern world as static, homogenous, intellectually weak, and underdeveloped. In contrast, they demonstrate the West as developed, superior, and rational (Said, 1978). Likewise, many Western scholars present Muslim countries, such as the states in the Middle East, as homogenous and radical. Said (1978) argued that although many Western scholars try to explore the Muslim communities through robust methodological means. However, in reality, they compare their values with the Muslim people, which produces faulty 
knowledge. Said (1978) also elucidated that some Eastern scholars reaffirm the Western ocular due to Western supremacy dominating the scholarship. Scholars have widely cited Said's $(1978,1992)$ work to decolonize the broader literature concerning the Muslim world (Roose \& Turner, 2019; Samiei, 2010).

On the other hand, Occidentalism refers to how some Eastern scholars perceive the West as inhumane, immoral, sinful, racist, a threat to religion, all-White, and market-driven (Buruma \& Margalit, 2005; Gill, 2004; Venn, 2000). This deep-rooted bias towards the West shapes the ideological values of some Eastern scholars (Buruma \& Margalit, 2005). Further, these researchers only see the West and its relationship with the East as noncompliant (Buruma and Margalit, 2005; Gill, 2004; Venn, 2000). The above two philosophical terrains create a broader discourse about the Muslim and the Western world (Buruma \& Margalit, 2005; Gill, 2004; Venn, 2000). In this study, I have grounded the Orientalism and Occidentalism notion in the clash of civilizations thesis to offer how a Muslim man athlete with intersecting identities can be seen differently in the Eastern and Western media. Hence, I expand Huntington's (1993) clash of civilizations thesis by arguing that the clash between the Muslim and Western world could be observed in the Orientalist and Occidentalist media discourse.

\section{Current Study Context: Khabib Nurmagomedov versus Conor McGregor}

Khabib Nurmagomedov retired with an undefeated record in 2020. However, the UFC 229 became a global front-page news-not due to Khabib Nurmagomedov winning the match and retaining his UFC title (Zidan, 2019), but more so because of Khabib Nurmagomedov's after match attack on Conor McGregor's ring-side team. This attack was in response to unceasing Islamophobic and racist slurs before and during the match by Conor McGregor and his team members (Zidan, 2019). Before the fight, Conor McGregor openly disparaged the Islamic faith of Khabib Nurmagomedov on social media and UFC's official platforms. For instance, Conor McGregor titled Khabib Nurmagomedov as a 'backward cunt' and offered him alcohol in the UFC 229 pre-fight press conference. Alcohol consumption is prohibited in Islam and perceived as disrespectful if offered to a Muslim. Conor McGregor also called Khabib Nurmagomedov's wife a 'towel mate' because she covered her face with Hijab in her wedding pictures (USA Today, 2019).

On the other hand, Khabib Nurmagomedov, in various media discussions, has openly discussed his strong Islamic beliefs being the cause of his unbeaten track record at the UFC against non-Muslim MMA fighters (Pugmire, 2018). Khabib Nurmagomedov also criticized the Western media for showing abhorrence towards his religious beliefs. The Russian fighter has also been criticized for not showing up with the Russian flag in the octagon but wearing an identifiable sheepskin headwear, 'the papakha' (Vestnik Kavkaza, 2018). In addition, after the victory against Conor McGregor, Khabib Nurmagomedov was invited by the Turkish and Russian Prime Minister to congratulate him on his victory on a personal basis. Thus, Khabib Nurmagomedov's victory was celebrated in the Muslim world as a victory against the West, which shows potential bias held in the Eastern world against the West. Therefore, Khabib Nurmagomedov versus Conor McGregor provides an interesting case study to understand how the clash between the West and the Eastern world could be observed in the sporting context by analyzing the popular discourse.

\section{Research Method}

Fairclough's $(1989,1995)$ model for critical discourse analysis (CDA) was used to understand the phenomenon. Fairclough's $(1989,1995)$ underscored that CDA entails three inter-related procedures of analysis that are tangled to three inter-related dimensions. The three dimensions are the identification of the object of study (e.g., newspapers, blogs, and websites), understanding the source of object creation (e.g., an event- Khabib Nurmagomedov v. Conor McGregor) by a human subject, and socio-historical perspectives about 
the phenomenon interpreted in the object of analysis. These three dimensions require three types of analysis: textual analysis, processing analysis, and social analysis. In this study, I did the textual analysis by exploring newspaper databases, online sporting websites, and blogs. I used an open coding system (Creswell, 1998) for processing analysis. Finally, using the theoretical framework and previous scholarship, I conducted a social analysis of the retrieved data.

\subsection{Data Collection}

Data was collected from the following newspaper databases: ProQuest Recent Newspapers, Google News, and Press Reader. Further, online sporting websites and blogs were analyzed through a google search. I also analyzed various top newspapers from the Eastern and the Western world via Google search. The keywords used were *Ultimate Fight Championship (UFC) 229, *Pay-per-view UFC 229, *Khabib Nurmagomedov Versus Conor McGregor, *Khabib Nurmagomedov and Conor McGregor, and *Khabib Nurmagomedov October 2018. The inclusion criteria were: First, the media outlet should have reported the news in English. Second, the news should be regarding Khabib Nurmagomedov versus Conor McGregor UFC 229 fight. Lastly, the national origin of the source is identifiable. For screening of media reports, Moher et al.'s (2009) PRISMA (preferred reporting items for systematic reviews and meta-analyses) approach was employed. I initially identified 480 media reports (i.e., newspapers, blogs, and sporting news websites), out of which 57 were deemed appropriate per the inclusion criteria (see Appendix A). The snapshot of the Western media outlets (i.e., newspapers, blogs, and sporting news websites) analysed is given in Appendix B, while the snapshot of the Eastern media platforms (i.e., newspapers, blogs, and sporting news websites) is presented in Appendix C.

\subsection{Data Analysis}

Elo and Kyngäs's (2008) three-phase content analysis procedure was employed for data analysis. The three phases are preparation, organization, and reporting. First, I prepared data by analyzing the sources of data collection. Second, data were organized using open coding (Creswell, 1998). Next, I combined open codes to develop themes (Corbin \& Strauss, 2008). Finally, I report the final themes in the result section using the selective coding method (Creswell, 1998).

\subsection{Positionality and Reflexivity}

Singer et al. (2019) underscored that clearly putting forward the researcher's positionality increases the trustworthiness of the research. In the recent past, sport management and sport sociology scholars have extensively written about Islamophobia, Orientalism, and colonized Western scholarship shaping the perception of Muslim athletes and the Muslim world (Hussain \& Cunningham, 2020; Ratna \& Samie, 2017; Samie, 2013, 2017; Samie \& Sehlikoglu 2014; Toffoletti \& Palmer, 2017). However, scholars' silence about how the Muslim world depicts the West signifies deep bias (Occidentalism) in sporting academia. Therefore, I accentuate that our service to the scholarship should not be based upon our religious and racial identity but upon understanding and reporting the contrasting and multiple realities. I am a practicing Muslim man from Pakistan working in the United States. My ontological view is that truth is socially constructed. Therefore, there exists no singular reality. While my epistemological opinion is that knowledge is negotiated and dynamic. Thereby, my worldview and research paradigm might have influenced this study.

\section{Results and Discussion}

\subsection{Western Media: The Orient within the Clash of Civilizations}

The content analysis of the Western media platforms (i.e., newspapers, blogs, and sporting news websites) unveiled deep racial and ethnic bias held against Khabib Nurmagomedov. In addition, his victory against Conor McGregor was overshadowed by focusing on his nuanced identity. Khabib Nurmagomedov was also blamed by the Western 
media (i.e., newspapers, blogs, and sporting news websites) for not being able to control his emotions. This reaffirms the primary notion of Orientalism that Muslim men are seen in the Western media as emotional and irrational.

\subsubsection{The Blame Game}

The first theme that emerged from data is the portrayal of Khabib Nurmagomedov as the culprit of the after fight-brawl and overshadowing his victory, as the BBC (2018), while quoting a popular blogger Ruslan Usachov from Russia, reported, "Official Rossiya 1 TV hails the Dagestani fighter as 'our Khabib' who 'almost literally tore McGregor's head off.' However, not all Russians were proud of Nurmagomedov. It is Khabib who won, but it is I who feel ashamed."

Likewise, the Bleacher's Report (Botter, 2018) headline was, "Khabib Nurmagomedov brought his best vs. Conor McGregor; then we saw his worst." Similarly, the headline of The New York Times (2018) was, "Khabib Nurmagomedov could face fine and suspension after brawl at UFC 229." Hence, The New York Times (2018) focused upon the afterfight brawl rather than celebrating Khabib Nurmagomedov's victory. Similarly, Business Insider (2018b), a US-based online website, blamed Khabib Nurmagomedov for his early actions to be the cause of disputes with Conor McGregor. For instance, the Business Insider (2018b) registered, "The bad blood between McGregor and Nurmagomedov, which was sparked when the Russian was seen on video slapping McGregor's team-mate Artem Lobov in April, has been well documented." This bias in the broader Western media (i.e., newspapers, blogs, and sporting news websites) remains despite UFC's various attempts to assimilate fighters from diverse ethnic and racial backgrounds. One can understand the incompatibility of Khabib Nurmagomedov's identity within the Western world via Feagin and Feagin's (2009) understanding of Gordon's (1964) work about why people of color face bias in the US.

Feagin and Feagin (2009) discussed three competing critical concepts of assimilation of people of color in a Westernized phenomenon: melting pot, cultural pluralism, and Anglo-conformity. The melting pot elucidates understanding in the West that people from diverse backgrounds should be made part of the harmonious stew. This provides an opportunity for various groups to be part of larger group phenomena. However, the stew itself is tilted towards bias understanding of race (Armstrong, 2011), escalating tension between the minority and the majority group. The other method of assimilation is via cultural pluralism. Cultural pluralism is described as a minority group being part of the majority group activity while maintaining their cultural differences (Feagin \& Feagin, 2009).

Nonetheless, keeping cultural differences can also be dangerous for the minority group because of unfathomable racial biases within society. For instance, Khabib Nurmagomedov is part of a Western phenomenon (i.e., UFC) while maintaining his religious identity. Though his religious and racial ethnicity directly clashes with the core values of the Western world. Thereby, Khabib Nurmagomedov and many other athletes like him might continuously face racial and ethnic bias in the West, despite being offered an opportunity to be part of a social event. Lastly, Anglo-conformity elucidates people of color being part of the West by following Anglo-White norms and traditions. This does not guarantee them an opportunity to be fully assimilated within the group because the majority will never consider them as part of the mainstream group (Armstrong, 2011). Consequently, the blame towards Khabib Nurmagomedov is natural and tilted towards a broader understanding of Khabib Nurmagomedov being incompatible with the AngloWhite norms and traditions.

6.2.2. The Russian Dagestani Muslim 
The second significant theme that emerged from Western media's (i.e., newspapers, blogs, and sporting news websites) data (see Appendix B) was the portrayal of Khabib Nurmagomedov as a Dagestani Russian Muslim with a discriminatory approach. For instance, many Western media outlets (i.e., newspapers, blogs, and sporting news websites) used the word Russian repeatedly with Khabib Nurmagomedov. In comparison, Conor McGregor's racial and ethnic identity was not widely used to describe the White Irish fighter within the same articles. For example, Reuters (2018) reported:

"For once the violence in the octagon looked secondary as a mass brawl ensued after Russian Khabib Nurmagomedov retained his UFC lightweight title with a submission win over Conor McGregor on Saturday."

Likewise, the Irish Examiner's (2018) headline was, "The UFC call him Russian but, like his hated rival, Khabib is much more complicated." On the contrary, British Broadcasting Corporation- BBC (2018) registered, "The Dagestani - who has never lost in his career - beat his Irish opponent in the fourth round of the Las Vegas mixed martial arts (MMA) fight." Though, BBC highlighted Conor McGregor's Irish identity but did not ponder upon his ethnic and racial background. However, Khabib Nurmagomedov's ethnic background of being Dagestani was the main emphasis of the BBC. In addition, many media outlets (e.g., Fox News and New York Times) highlighted Khabib Nurmagomedov's religious identity of being Muslim. In comparison, not even one outlet discussed Conor McGregor's religious identity.

The above examples illustrate the potential racial and religious bias against Khabib Nurmagomedov. This bias is not only limited to Khabib Nurmagomedov's religious beliefs but against his ethnic and racial background. The discrimination against Khabib Nurmagomedov depicts how Muslim athletes' identities are being universalized and homogenized. This bias towards Khabib Nurmagomedov cements the notion of Orientalism lying in the Western discourse (Said, 1978). Thus, there exists a potential racial, ethnic, and religious bias against Khabib Nurmagomedov's national, ethnic, and religious identity in the Western media (i.e., newspapers, blogs, and sporting news websites).

\subsection{The Eastern Media: The Occidentalism within the Clash of Civilization}

Analysis of the Eastern media (i.e., newspapers, blogs, and sporting news websites) uncovered a positive bias towards Khabib Nurmagomedov's action (after fight brawl) due to his religious identity (see Appendix C). Further, Khabib Nurmagomedov was portrayed as a Muslim Messiah fighting against the infidel Western world. This biased media approach by homogenizing the Western world as all-infidel and Islamophobic depicts the Eastern world's media's deep racial bias towards the West.

\subsubsection{The Innocent Hero of the East against the Infidel}

The Eastern media (i.e., newspapers, blogs, and sporting news websites) also highlighted Khabib Nurmagomedov's religious identity but in a triumph tone. For instance, Aljazeera (2018) reported, "Violent scenes occurred inside and outside the cage on Saturday night after McGregor tapped out in the fourth round of his comeback Ultimate Fighting Championship (UFC) bout against the undefeated Muslim champion." Likewise, the Arab News (2018) reported, "The 30-year-old Muslim pleaded that he was not to blame for the sorry post-fight scenes. This is not my best side. He talked about my religion, my country, my father." The Express Tribune, a Pakistani newspaper headline was, "McGregor can pass racist and Islamophobic insults, but Nurmagomedov can't react to it?" Thereby, Khabib Nurmagomedov's after-match actions were justified because of his religious identity. Muharram (2014) argued that many Islamists view the West as religious ignorant, and barbaric. This leads to a broader affirmation that hostile acts against the Western world are justified and should be supported (Muharram, 2014). 
Buruma and Margalit (2005) claimed that Occidentalists view the West as a bourgeois society hooked to individual luxuries and selfishness. Hence, in the eye of Occidentalism, West is a fraidy-cat who awards life above bereavement (Buruma \& Margalit, 2005). In the results, I found out that there was an inherent belief that Khabib Nurmagomedov was fighting against coward infidels who does not have any ethical values. For instance, the Turkish Radio and Television Corporation World-TRT (2020) headline was, "Khabib: An unabashedly Muslim champion in an Islamophobic world." Similarly, the South China Morning Post (2018) headline after Khabib Nurmagomedov being congratulated by the Russian President was, "UFC: Khabib and Vladimir Putin throw shade at Conor McGregor as Russian president praises chokehold." This highlights that the 'chokehold' of Khabib Nurmagomedov was portrayed as a sign of walloping Conor McGregor. Thereby, hostility against Conor McGregor was endorsed and celebrated in the Eastern world. In contrast, the Western media (i.e., newspapers, blogs, and sporting news websites) depicted the chokehold as a means to take off Conor McGregor's head (BBC, 2018).

The Eastern media (i.e., newspapers, blogs, and sporting news websites) also portrayed Khabib Nurmagomedov as a savior of the Muslim world compared to other Muslim athletes. For instance, Al-Qalam's, Southern Africa's Muslim Newspaper, the headline was, "Khabib '100 times bigger than Mo Salah' after winning for the Muslim world." Khabib Nurmagomedov's victory was considered as the Muslim world victory. Overall, it can be argued that Khabib Nurmagomedov was portrayed as a Muslim Messiah fighting against the coward Islamophobic West. This categorization of the Western world to be all Islamophobic depicts potential deep racial bias against the West in the East, confirming Occidentalism notion in the Eastern world.

\section{Conclusion}

In the early 1990s, the clash of civilizations thesis was used to predict the West and the Muslim world's potential conflict. Numerous scholars have claimed that the clash of civilizations thesis has been substantiated due to ongoing disputes between the West and the Muslim world after the 9/11 terrorist attacks (e.g., the Aghan war, Syrian War, Iraq War, and Libya War) (Haynes, 2019). Further, the clash of civilizations thesis was mainly hypothesized to decipher the explicit bias held among various civilizations due to historical reasons (Huntington, 1993). However, scholars have argued that the clash of civilizations thesis can offer means to understand implicit bias among various civilizations in social activities, such as sports (Dyreson, 2010, 2012). In this study, I have examined the clash of civilizations thesis through the lens of Orientalism and Occidentalism notion. I argue that a Muslim athlete with an intersecting identity can be seen in a contrasting way in the Muslim and Eastern world media. This study adds to the body of knowledge by elucidating that civilizations' clashes could be witnessed in the sporting phenomenon.

Notably, in the sociology of sport scholarship, researchers have already highlighted that the Muslim world is perceived as a homogenous and monolithic entity by the Western world (Ratna \& Samie, 2016; Samie, 2013, 2017). This study contributes to the sport sociology scholarship by highlighting that the Muslim world media also sees the West as all-homogenous and racist, which shows deep contrasting racial bias in both civilizations. In the future, research is needed about how Muslim women athletes are seen in both the Western and Eastern worlds. Although, there has been some research about how Muslim women athletes are being comprehended in the Western media (Samie \& Sehlikoglu, 2014). For instance, Samie and Sehlikoglu (2014) conducted a critical analysis of numerous online media platforms to understand how the Western media painted Muslim women from 28 different countries during the 2012 London Olympic Games. They found out that most of the Western media described Muslim women as out of place, incompetent, in need of Western men's help, and exotic veiled objects. However, missing from the scholarship is how Western and Eastern media portrays Muslim women athletes' participation in one sporting event in a contrasting way. Further, I request scholars to take a more holistic approach in understanding the Muslim athletes' identity portrayal by media via 
highlighting contrasting views, rather than only stressing upon Islamophobia and Orientalist bias in the Western world. Lastly, in the future, a study could be conducted concerning how Western media portrays Western minority athletes as compared to Muslim athletes from the Eastern world.

\section{Appendix A: Data Screening Strategy}
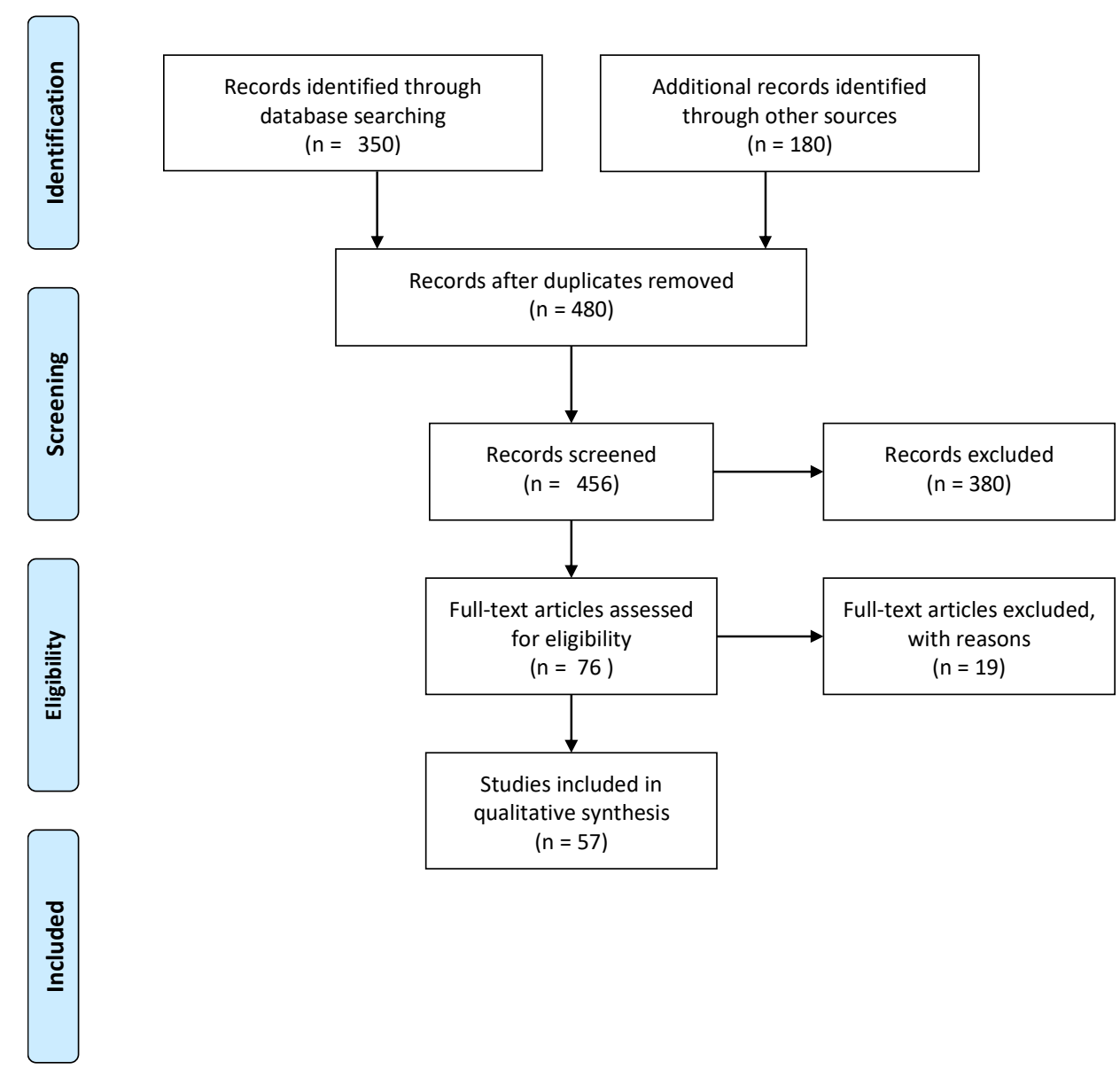
Appendix B: The Snapshot of the Major Western Media News Outlets.

\begin{tabular}{|c|c|c|c|c|}
\hline \multicolumn{2}{|c|}{ Newspaper/Blog/Website } & Headline & Origin & $\begin{array}{c}\text { Source } \\
\end{array}$ \\
\hline & 1. Fox News & $\begin{array}{l}\text { Khabib Nurmagomedov } \\
\text { faces } \$ 2 \mathrm{M} \text { fine for post- } \\
\text { fight melee }\end{array}$ & USA & $\begin{array}{l}\text { https://www.foxnews.co } \\
\text { m/entertainment/kha- } \\
\text { bib-nurmagomedov- } \\
\text { faces-2m-fine-for-post- } \\
\text { fight-melee-report } \\
\end{array}$ \\
\hline 2. & The Guardian & $\begin{array}{l}\text { Vladimir Putin sympa- } \\
\text { thises with Nurmagome- } \\
\text { dov over McGregor brawl }\end{array}$ & UK. & $\begin{array}{l}\text { https://www.theguard- } \\
\text { ian.com/sport/2018/oct/1 } \\
\text { 0/vladimir-putin-kha- } \\
\text { bib-nurmagomedov- } \\
\text { conor-mcgregor-ufc-229 }\end{array}$ \\
\hline $\begin{array}{l}3 . \quad \text { Radio } \\
\text { Liberty }\end{array}$ & o Free Europe/Radio & $\begin{array}{l}\text { Sucker Punch? Many Rus- } \\
\text { sians Back Irish Fighter } \\
\text { McGregor Over Daghe- } \\
\text { stani Khabib In UFC } 229\end{array}$ & USA & $\begin{array}{c}\text { https://www.rferl.org/a/ } \\
\text { below-the-belt-many- } \\
\text { russians-back-irish- } \\
\text { fighter-over-local-da- } \\
\text { ghestani-for-mma- } \\
\text { champion- } \\
\text { ship/29523686.html } \\
\end{array}$ \\
\hline 4. & Business Insider & $\begin{array}{l}\text { Vladimir Putin told Kha- } \\
\text { bib Nurmagomedov's fa- } \\
\text { ther to cut him some slack } \\
\text { after he incited a riot at } \\
\text { UFC } 229\end{array}$ & USA & $\begin{array}{l}\text { https://www.busi- } \\
\text { nessinsider.com/vladi- } \\
\text { mir-putin-told-khabib- } \\
\text { nurmagomedov-father- } \\
\text { to-cut-him-some-slack- } \\
\text { 2018-10 } \\
\end{array}$ \\
\hline 5. & Bleacher Report & $\begin{array}{l}\text { Conor McGregor vs. Kha- } \\
\text { bib Nurmagomedov Is a } \\
\text { Study of Contrasts }\end{array}$ & USA & $\begin{array}{c}\text { https://bleacherre- } \\
\text { port.com/arti- } \\
\text { cles/2797108-conor- } \\
\text { mcgregor-vs-khabib- } \\
\text { nurmagomedov-is-a- } \\
\text { study-of-contrasts } \\
\end{array}$ \\
\hline 6. & Sporting News & $\begin{array}{l}\text { Khabib Nurmagomedov } \\
\text { rejects fighting 'idiot' } \\
\text { Conor McGregor again, } \\
\text { even for } \$ 100 \mathrm{M}\end{array}$ & USA & $\begin{array}{c}\text { https://www.sporting- } \\
\text { news.com/us/mma/new } \\
\text { s/conor-mcgregor-kha- } \\
\text { bib-nurmagomedov- } \\
\text { ufc- }\end{array}$ \\
\hline 7. & ESPN & $\begin{array}{l}\text { Post-fight brawl ensues af- } \\
\text { ter Khabib Nurmagome- } \\
\text { dov submits Conor } \\
\text { McGregor }\end{array}$ & USA & $\begin{array}{c}\text { https://www.espn.com/ } \\
\text { mma/story/_/id/2491611 } \\
\text { 1/khabib-nurmagome- } \\
\text { dov-defeats-conor- } \\
\text { mcgregor-submission- } \\
\text { ufc-229-main-event } \\
\end{array}$ \\
\hline 8. & The Sun & $\begin{array}{l}\text { 'SMASHED AGAIN' Kha- } \\
\text { bib Nurmagomedov camp } \\
\text { tell Conor McGregor to } \\
\text { 'bring security' to UFC } 242 \\
\text { in Abu Dhabi after Notori- } \\
\text { ous' Muslim jibe }\end{array}$ & UK. & $\begin{array}{l}\text { https://www.thesun.co. } \\
\text { uk/sport/9430984/kha- } \\
\text { bib-nurmagomedovs- } \\
\text { camp-send-warning-to- } \\
\text { conor-mcgregor-ahead- } \\
\text { of-ufc-242-you-better- } \\
\text { bring-security-with- } \\
\text { you-to-abu-dhabi/ }\end{array}$ \\
\hline 9. & The Mirror & $\begin{array}{l}\text { Conor McGregor vs Kha- } \\
\text { bib Nurmagomedov: Rus- } \\
\text { sian's cousin reveals }\end{array}$ & UK. & $\begin{array}{l}\text { https://www.mir- } \\
\text { ror.co.uk/sport/other- } \\
\text { sports/mma/damage- }\end{array}$ \\
\hline
\end{tabular}




\begin{tabular}{|c|c|c|c|c|}
\hline & & $\begin{array}{l}\text { damage "Irish } b^{* * * * *} \mathrm{~d}^{\prime} \\
\text { caused in UFC } 229 \text { brawl }\end{array}$ & & $\begin{array}{c}\text { conor-mcgregor-in- } \\
\text { flicted-khabib-13380104 }\end{array}$ \\
\hline & 10. Irish Examiner & $\begin{array}{l}\text { The UFC call him Russian } \\
\text { but, like his hated rival, } \\
\text { Khabib is much more com- } \\
\text { plicated }\end{array}$ & Ireland & $\begin{array}{l}\text { https://www.irishexa- } \\
\text { miner.com/sport/arid- } \\
\text { 30873697.html }\end{array}$ \\
\hline & Daily Mail & $\begin{array}{l}\text { Khabib Nurmagomedov } \\
\text { submits Conor McGregor } \\
\text { in fourth round of epic } \\
\text { UFC } 229 \text { title fight before } \\
\text { chaos descends as Russian } \\
\text { jumps into the crowd to } \\
\text { fight Irishman's team- } \\
\text { mate Dillon Danis - then } \\
\text { McGregor is PUNCHED } \\
\text { in head by members of } \\
\text { Khabib's team }\end{array}$ & UK. & $\begin{array}{l}\text { https://www.dai- } \\
\text { lymail.co.uk/sport/mma } \\
\text { /article-6248751/Khabib- } \\
\text { Nurmagomedov-beats- } \\
\text { Conor-McGregor-sub- } \\
\text { mission-win.html }\end{array}$ \\
\hline & Bleacher Report & $\begin{array}{l}\text { Khabib Nurmagomedov } \\
\text { brought his best vs. Conor } \\
\text { Mcgregor; then we saw his } \\
\text { worst }\end{array}$ & USA & $\begin{array}{c}\text { https://bleacherre- } \\
\text { port.com/arti- } \\
\text { cles/2799490-khabib- } \\
\text { nurmagomedov- } \\
\text { brought-his-best-vs- } \\
\text { conor-mcgregor-then- } \\
\text { we-saw-his-worst } \\
\end{array}$ \\
\hline & Reuters & $\begin{array}{l}\text { Brawls overshadow Kha- } \\
\text { bib's UFC title win over } \\
\text { McGregor }\end{array}$ & $\begin{array}{l}\text { United King- } \\
\text { dom }\end{array}$ & $\begin{array}{c}\text { https://www.reu- } \\
\text { ters.com/article/us- } \\
\text { mma-ufc-ufc229- } \\
\text { brawls/brawls-over- } \\
\text { shadow-khabibs-ufc-ti- } \\
\text { tle-win-over-mcgregor- } \\
\text { idUSKCN1MH09P }\end{array}$ \\
\hline \multirow[t]{3}{*}{14.} & $\begin{array}{l}\text { British Broadcasting Cor- } \\
\text { poration }(\mathrm{BBC})\end{array}$ & $\begin{array}{c}\text { Khabib Nurmagomedov v } \\
\text { Conor McGregor: Dage- } \\
\text { stan celebrates win }\end{array}$ & $\begin{array}{l}\text { United King- } \\
\text { dom }\end{array}$ & $\begin{array}{c}\text { https://www.bbc.com/n } \\
\text { ews/world-europe- } \\
45782513 \\
\end{array}$ \\
\hline & 15. Talk Sports & $\begin{array}{c}\text { Conor McGregor opens up } \\
\text { on brawl with 'rat' Khabib } \\
\text { Nurmagomedov and says } \\
\text { 'let's go again' }\end{array}$ & $\begin{array}{l}\text { United King- } \\
\text { dom }\end{array}$ & $\begin{array}{c}\text { https://talk- } \\
\text { sport.com/sport/mma/5 } \\
\text { 47507/conor-mcgregor- } \\
\text { brawl-rat-khabib- } \\
\text { nurmagomedov/ } \\
\end{array}$ \\
\hline & 16. Irish Post & $\begin{array}{l}\text { Conor McGregor issues } \\
\text { threat to 'scurrying rat' } \\
\text { Khabib Nurmagomedov } \\
\text { ahead of UFC comeback }\end{array}$ & Ireland & $\begin{array}{c}\text { https://www.irish- } \\
\text { post.com/news/conor- } \\
\text { mcgregor-khabib- } \\
\text { nurmagomedov-insult- } \\
175822 \\
\end{array}$ \\
\hline \multirow[t]{2}{*}{17.} & $\begin{array}{l}\text { International Business } \\
\text { Times (IBTimes) }\end{array}$ & $\begin{array}{l}\text { Scurrying Rat! That's what } \\
\text { Conor McGregor called } \\
\text { Khabib Nurmagomedov to } \\
\text { challenge him }\end{array}$ & USA & $\begin{array}{l}\text { https://www.ibtimes.sg/ } \\
\text { scurrying-rat-thats- } \\
\text { what-conor-mcgregor- } \\
\text { called-khabib-nurma- } \\
\text { gomedov-challenge- } \\
\text { him-36253 } \\
\end{array}$ \\
\hline & 18. Sport Business & $\begin{array}{l}\text { The McGregor effect: UFC } \\
229 \text { almost sells out within } \\
\text { three minutes }\end{array}$ & USA & $\begin{array}{l}\text { https://test.sportbusi- } \\
\text { ness.com/news/the- } \\
\text { mcgregor-effect-ufc-229- } \\
\text { almost-sells-out-within- } \\
\text { three-minutes/ }\end{array}$ \\
\hline
\end{tabular}




\begin{tabular}{|c|c|c|c|c|c|}
\hline 19. & & he New York Times & $\begin{array}{l}\text { Khabib Nurmagomedov } \\
\text { Could Face Fine and Sus- } \\
\text { pension After Brawl at } \\
\text { UFC } 229\end{array}$ & USA & $\begin{array}{c}\text { https://www.ny- } \\
\text { times.com/2018/10/07/sp } \\
\text { orts/mcgregor-khabib- } \\
\text { ufc-229.html }\end{array}$ \\
\hline & 20. & Bleach Report & $\begin{array}{l}\text { Khabib Nurmagomedov } \\
\text { Mocks Conor McGregor: } \\
\text { 'This Is Not a Burger } \\
\text { King's Sport' }\end{array}$ & USA & $\begin{array}{c}\text { https://bleacherre- } \\
\text { port.com/arti- } \\
\text { cles/2764330-khabib- } \\
\text { nurmagomedov-mocks- } \\
\text { conor-mcgregor-this-is- } \\
\text { not-a-burger-kings- } \\
\text { sport } \\
\end{array}$ \\
\hline & 21. & CBSS Sport & $\begin{array}{l}\text { UFC } 229 \text { results, Khabib } \\
\text { vs. McGregor highlights: } \\
\text { All hell breaks loose after } \\
\text { Nurmagomedov wins }\end{array}$ & USA & $\begin{array}{l}\text { https://www.cbssports.c } \\
\text { om/mma/news/ufc-229- } \\
\text { results-all-hell-breaks- } \\
\text { loose-as-khabib-nurma- } \\
\text { gomedov-submits- } \\
\text { conor-mcgregor/ }\end{array}$ \\
\hline & 22. & ESPN News & $\begin{array}{c}\text { Post-fight brawl ensues af- } \\
\text { ter Khabib Nurmagome- } \\
\text { dov submits Conor } \\
\text { McGregor }\end{array}$ & USA & $\begin{array}{c}\text { https://www.espn.com/ } \\
\text { mma/story/_/id/2491611 } \\
\text { 1/khabib-nurmagome- } \\
\text { dov-defeats-conor- } \\
\text { mcgregor-submission- } \\
\text { ufc-229-main-event } \\
\end{array}$ \\
\hline & 23. & NBC Sports & $\begin{array}{c}\text { Melee at UFC } 229 \text { after } \\
\text { Nurmagomedov chokes } \\
\text { out McGregor }\end{array}$ & UK & $\begin{array}{c}\text { https://www.espn.com/ } \\
\text { mma/story/_/id/2491611 } \\
\text { 1/khabib-nurmagome- } \\
\text { dov-defeats-conor- } \\
\text { mcgregor-submission- } \\
\text { ufc-229-main-event } \\
\end{array}$ \\
\hline 24. & & he New York Times & $\begin{array}{l}\text { McGregor vs. Nurma- } \\
\text { gomedov: Notorious Is } \\
\text { Back }\end{array}$ & USA & $\begin{array}{c}\text { https://www.ny- } \\
\text { times.com/2018/10/05/sp } \\
\text { orts/conor-mcgregor- } \\
\text { khabib-nurmagomedov- } \\
\text { ufc-229.html } \\
\end{array}$ \\
\hline 25. & & he Washington Post & $\begin{array}{c}\text { Conor McGregor accuses } \\
\text { Khabib Nurmagomedov's } \\
\text { manager of being a terror- } \\
\text { ist }\end{array}$ & USA & $\begin{array}{c}\text { https://www.washing- } \\
\text { tonpost.com/sports/2018 } \\
\text { /10/05/conor-mcgregor- } \\
\text { accuses-khabib-nurma- } \\
\text { gomedovs-manager-be- } \\
\text { ing-terrorist/ } \\
\end{array}$ \\
\hline & 26. & Undefeated & $\begin{array}{l}\text { Bigotry fueled the Conor } \\
\text { McGregor-Khabib Nurma- } \\
\text { gomedov brawl after UFC } \\
\text { 229. The Undefeated. }\end{array}$ & USA & $\begin{array}{c}\text { https://theunde- } \\
\text { feated.com/features/big- } \\
\text { otry-fueled-the-conor- } \\
\text { mcgregor-khabib- } \\
\text { nurmagomedov-brawl- } \\
\text { after-ufc-229/ } \\
\end{array}$ \\
\hline & 27. & Daily Mail & $\begin{array}{l}\text { Conor McGregor claims } \\
\text { bitter rival Khabib Nurma- } \\
\text { gomedov will be's ****ing } \\
\text { his pants' during fight } \\
\text { with Justin Gaethje as he } \\
\text { jokes that UFC lightweight } \\
\text { champion will dive at his } \\
\text { opponent's legs 'for a } \\
\text { good whiff of his jock- } \\
\text { strap' }\end{array}$ & UK. & $\begin{array}{c}\text { https://www.dai- } \\
\text { lymail.co.uk/sport/mma } \\
\text { /article-8591587/Conor- } \\
\text { McGregor-claims-Kha- } \\
\text { bib-Nurmagomedov-s- } \\
\text { ing-pants-fight-Justin- } \\
\text { Gaethje.html }\end{array}$ \\
\hline
\end{tabular}




\begin{tabular}{|c|c|c|c|c|}
\hline 28. & USA Today & $\begin{array}{l}\text { Khabib's manager calls } \\
\text { Conor McGregor a 'horri- } \\
\text { ble human being' }\end{array}$ & USA & $\begin{array}{c}\text { https://www.usato- } \\
\text { day.com/story/sports/m } \\
\text { ma/2018/10/07/khabib- } \\
\text { manager-says-conor- } \\
\text { mcgregor-not-good- } \\
\text { guy-ucf-229/1560064002/ }\end{array}$ \\
\hline & Reuters & $\begin{array}{c}\text { Brawls overshadow Kha- } \\
\text { bib's UFC title win over } \\
\text { McGregor }\end{array}$ & UK & $\begin{array}{c}\text { https://www.reu- } \\
\text { ters.com/article/us- } \\
\text { mma-ufc-ufc229/arrests- } \\
\text { after-nurmagomedov- } \\
\text { beats-mcgregor- } \\
\text { idUSKCN1MH053 }\end{array}$ \\
\hline & MSN & $\begin{array}{l}\text { Conor McGregor is } \\
\text { slammed over 'racist' } \\
\text { tweet branding Muslim } \\
\text { UFC rival Khabib Nurma- } \\
\text { gomedov's wife a 'towel' }\end{array}$ & USA & $\begin{array}{c}\text { https://www.msn.com/e } \\
\text { n-au/sport/mma/conor- } \\
\text { mcgregor-is-slammed- } \\
\text { over-racist-tweet-brand- } \\
\text { ing-muslim-ufc-rival- } \\
\text { khabib-nurmagome- } \\
\text { dovs-wife-a-towel/ar- } \\
\text { BBVyW17 }\end{array}$ \\
\hline 31 & 1. Fox News & $\begin{array}{c}\text { UFC champ Nurmagome- } \\
\text { dov a conservative voice } \\
\text { in Russia }\end{array}$ & USA & $\begin{array}{l}\text { https://www.foxnews.co } \\
\text { m/world/ufc-champ- } \\
\text { nurmagomedov-a-con- } \\
\text { servative-voice-in-russia }\end{array}$ \\
\hline 32. & The Guardian & $\begin{array}{c}\text { 'Politics forever': } \\
\text { McGregor fined } \$ 50,000, \\
\text { Nurmagomedov } \$ 500,000 \\
\text { for UFC } 229 \text { brawl }\end{array}$ & UK & $\begin{array}{c}\text { https://www.theguard- } \\
\text { ian.com/sport/2019/jan/2 } \\
\text { 9/conor-mcgregor- } \\
\text { banned-six-months-kha- } \\
\text { bib-nurmagomedov- } \\
\text { brawlufc-229 } \\
\end{array}$ \\
\hline 33. & The Washington Post & $\begin{array}{c}\text { Conor McGregor, Khabib } \\
\text { Nurmagomedov sus- } \\
\text { pended for their UFC } 229 \\
\text { brawl }\end{array}$ & USA & $\begin{array}{c}\text { https://www.washing- } \\
\text { tonpost.com/sports/2019 } \\
\text { /01/29/conor-mcgregor- } \\
\text { khabib-nurmagomedov- } \\
\text { suspended-their-ufc- } \\
\text { brawl/ }\end{array}$ \\
\hline 34. & The Denver Post & $\begin{array}{c}\text { Khabib Nurmagomedov, } \\
\text { Conor McGregor sus- } \\
\text { pended, fined for UFC } 229 \\
\text { brawl }\end{array}$ & USA & $\begin{array}{c}\text { https://www.den- } \\
\text { verpost.com/2019/01/29/ } \\
\text { khabib-nurmagomedov- } \\
\text { conor-mcgregor-ufc- } \\
\text { 229-brawl-suspensions/ }\end{array}$ \\
\hline 35. & Los Angeles Times & $\begin{array}{l}\text { Conor McGregor and Kha- } \\
\text { bib Nurmagomedov sus- } \\
\text { pended for brawl after } \\
\text { UFC } 229\end{array}$ & USA & $\begin{array}{l}\text { https://www.latimes.co } \\
\text { m/sports/boxing/la-sp- } \\
\text { conor-mcgregor-khabib- } \\
\text { nurmagomedov-sus- } \\
\text { pended-20190129- } \\
\text { story.html }\end{array}$ \\
\hline 36. & USA Today & $\begin{array}{l}\text { Khabib Nurmagomedov, } \\
\text { Conor McGregor sus- } \\
\text { pended for UFC } 229 \text { brawl }\end{array}$ & USA & $\begin{array}{c}\text { https://www.usato- } \\
\text { day.com/story/sports/m } \\
\text { ma/2019/01/29/khabib- } \\
\text { nurmagomedov-conor- } \\
\text { mcgregor-suspended- } \\
\text { for-ufc-229- } \\
\text { brawl/38971999/ }\end{array}$ \\
\hline
\end{tabular}




\begin{tabular}{|c|c|c|c|c|}
\hline & CNN & $\begin{array}{l}\text { UFC: Conor McGregor } \\
\text { comeback ends in defeat } \\
\text { amid chaotic scenes }\end{array}$ & USA & $\begin{array}{c}\text { https://www.cnn.com/2 } \\
\text { 018/10/07/sport/ufc-229- } \\
\text { conor-mcgregor-intl/in- } \\
\text { dex.html }\end{array}$ \\
\hline 38. & Business Insider & $\begin{array}{l}\text { Khabib Nurmagomedov } \\
\text { taunts Conor McGregor by } \\
\text { calling him 'slow' in his } \\
\text { first Instagram since vic- } \\
\text { tory. }\end{array}$ & USA & $\begin{array}{l}\text { https://www.busi- } \\
\text { nessinsider.in/sports/kh } \\
\text { abib-nurmagomedov- } \\
\text { taunts-conor-mcgregor- } \\
\text { by-calling-him-slow-in- } \\
\text { his-first-instagram- } \\
\text { since-victory/arti- } \\
\text { cleshow/66124172.cms }\end{array}$ \\
\hline
\end{tabular}

Appendix C: The Snapshot of the Major Eastern Media News Outlets

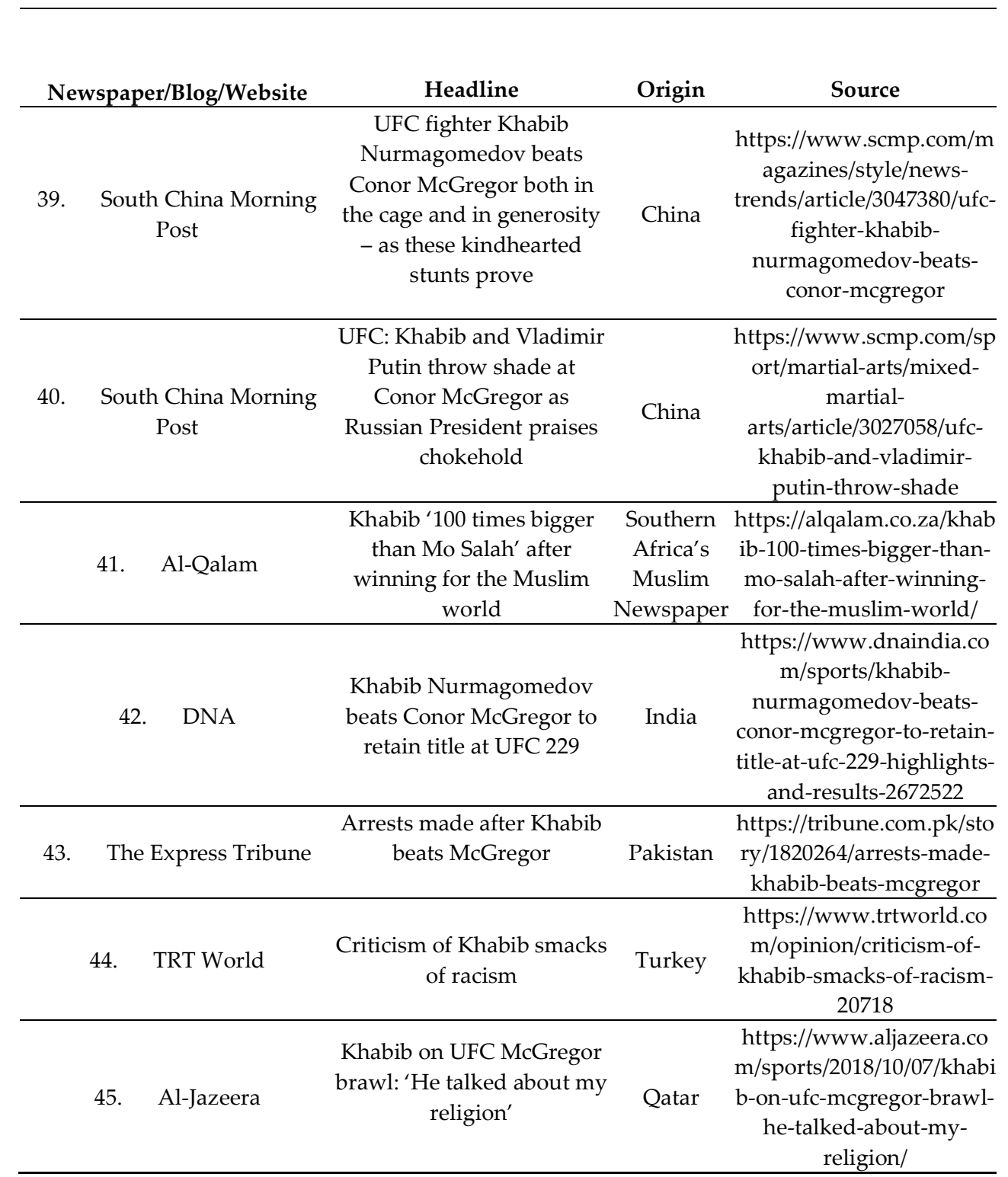




\begin{tabular}{|c|c|c|c|c|}
\hline 46. & The Hindu & $\begin{array}{l}\text { Khabib defeats McGregor } \\
\text { to retain title before } \\
\text { mayhem mars UFC } 229 \\
\text { UFC 229: Conor } \\
\text { McGregor's return to UFC } \\
\text { after a two-year hiatus } \\
\text { ended in a resounding } \\
\text { defeat to lightweight } \\
\text { champion Khabib } \\
\text { Nurmagomedov. }\end{array}$ & India & $\begin{array}{c}\text { https://sportstar.thehindu. } \\
\text { com/other-sports/ufc-229- } \\
\text { khabib-nurmagomedov- } \\
\text { defeats-conor-mcgregor- } \\
\text { to-retain-lightweight-title- } \\
\text { brawl-erupts-after-fight- } \\
\text { highlights- } \\
\text { updates/article25148345.e } \\
\text { ce }\end{array}$ \\
\hline 47. & Arab News & $\begin{array}{l}\text { Khabib Nurmagomedov } \\
\text { claims Conor McGregor } \\
\text { make offensive remarks } \\
\text { about his Muslim faith } \\
\text { after post-fight brawl }\end{array}$ & $\begin{array}{l}\text { Saudi } \\
\text { Arabia }\end{array}$ & $\begin{array}{l}\text { https://www.arabnews.co } \\
\text { m/node/1384006/sport }\end{array}$ \\
\hline 48. & uala Lampur News & $\begin{array}{l}\text { Khabib: Im ready to face } \\
\text { Conor McGregor }\end{array}$ & Malaysia & $\begin{array}{c}\text { https://www.kualalumpur } \\
\text { news.net/news/266093940 } \\
\text { /khabib-im-ready-to-face- } \\
\text { conor-mcgregor } \\
\end{array}$ \\
\hline & 19. Dawn & $\begin{array}{c}\text { Melee at UFC } 229 \text { after } \\
\text { Nurmagomedov chokes } \\
\text { out McGregor }\end{array}$ & Pakistan & $\begin{array}{c}\text { Melee at UFC } 229 \text { after } \\
\text { Nurmagomedov chokes } \\
\text { out McGregor }\end{array}$ \\
\hline 50. & Daily Sabah & $\begin{array}{l}\text { Nurmagomedov, } \\
\text { McGregor suspended, } \\
\text { fined for UFC } 229 \text { brawl }\end{array}$ & Turkey & $\begin{array}{c}\text { https://www.dailysabah.c } \\
\text { om/sports/2019/01/31/nur } \\
\text { magomedov-mcgregor- } \\
\text { suspended-fined-for-ufc- } \\
\text { 229-brawl }\end{array}$ \\
\hline 51. & Khaleej Times & $\begin{array}{l}\text { UFC 229: Khabib } \\
\text { Nurmagomedov beats } \\
\text { Conor McGregor }\end{array}$ & UAE & $\begin{array}{l}\text { https://www.khaleejtimes. } \\
\text { com/photos/sports/ufc- } \\
\text { 229-khabib- } \\
\text { nurmagomedov-beats- } \\
\text { conor-mcgregor }\end{array}$ \\
\hline 52. & The Gulf Times & $\begin{array}{l}\text { Scurrying rat! That's what } \\
\text { conor mcgregor called } \\
\text { khabib nurmagomedov to } \\
\text { challenge him }\end{array}$ & Qatar & $\begin{array}{l}\text { https://www.gulftimes.co } \\
\text { m/golf/story/scurrying- } \\
\text { rat-thats-what-conor- } \\
\text { mcgregor-called-khabib- } \\
\text { nurmagomedov-to- } \\
\text { challenge-him } \\
\end{array}$ \\
\hline 53. & Republic World & $\begin{array}{l}\text { ‘Conor McGregor Begged } \\
\text { Me Not To Kill Him': } \\
\text { Khabib Nurmagomedov } \\
\text { On Their UFC } 229 \text { Bout }\end{array}$ & India & $\begin{array}{l}\text { https:/www.republicworl } \\
\text { d.com/sports-news/other- } \\
\text { sports/mcgregor-begged- } \\
\text { me-not-to-kill-him- } \\
\text { khabib-on-their-ufc-229- } \\
\text { bout.html } \\
\end{array}$ \\
\hline 54. & RT News & $\begin{array}{c}\text { 'Revenge will be SWEET': } \\
\text { McGregor team-mate } \\
\text { Dillon Danis SLAMS } \\
\text { Khabib's team as } \\
\text { COWARDS over footage of } \\
\text { infamous UFC brawl } \\
\text { (VIDEO) }\end{array}$ & \multicolumn{2}{|c|}{$\begin{array}{l}\text { Worldwide https://www.rt.com/sport/ } \\
\text { (Origin } \\
\text { Russia } \\
\text { mcgregor-khabib/ }\end{array}$} \\
\hline
\end{tabular}




\begin{tabular}{|c|c|c|c|c|c|}
\hline & 55. & Sports Keeda & Khabib vs McGregor & India & $\begin{array}{l}\text { https://www.sportskeeda. } \\
\text { com/mma/khabib-vs- } \\
\text { mcgregor }\end{array}$ \\
\hline 56. & & he Express Tribune & $\begin{array}{l}\text { McGregor can pass racist } \\
\text { and Islamophobic insults, } \\
\text { but Nurmagomedov can't } \\
\text { react to it? }\end{array}$ & Pakistan & $\begin{array}{l}\text { https://tribune.com.pk/art } \\
\text { icle/72808/mcgregor-can- } \\
\text { pass-racist-and- } \\
\text { islamophobic-insults-but- } \\
\text { nurmagomedov-cant- } \\
\text { react-to-it }\end{array}$ \\
\hline & 57. & TRT World & $\begin{array}{l}\text { Khabib: An unabashedly } \\
\text { Muslim champion in an } \\
\text { Islamophobic world }\end{array}$ & Turkey & $\begin{array}{c}\text { https://www.trtworld.co } \\
\text { m/opinion/khabib-an- } \\
\text { unabashedly-muslim- } \\
\text { champion-in-an- } \\
\text { islamophobic-world- } \\
40866\end{array}$ \\
\hline
\end{tabular}

\section{References}

Ahmed, S., \& Matthes, J. (2016). Media representation of Muslims and Islam from 2000 to 2015: A meta-analysis. International Communication Gazette, 79(3), 219-244. https://doi.org/10.1177/1748048516656305

Al-Jazeera. (2018, October 7). Khabib on UFC McGregor brawl: 'He talked about my religion.' Al-Jazeera. https://www.aljazeera.com/sports/2018/10/07/khabib-on-ufc-mcgregor-brawl-he-talked-about-my-religion/

Arab News (2018, October 7). Khabib Nurmagomedov claims Conor McGregor make offensive remarks about his Muslim faith after post-fight brawl. Arab News. https://www.arabnews.com/node/1384006/sport

Armstrong, K. L. (2011). 'Lifting the veils and illuminating the shadows': Furthering the explorations of race and ethnicity in sport management. Journal of Sport Management, 25(2), 95-106. https://doi.org/10.1123/jsm.25.2.95

Bandyopadhyay, K. (2007). Pakistani Cricket at Crossroads: An Outsider's Perspective. Sport in Society, 10(1), 101-119. https://doi.org/10.1080/17430430600989191

Billingham, N. (2014, June 6). USA vs Iran at France '98: the most politically charged game in World Cup history. Fourfourtwo.Com. https://www.fourfourtwo.com/us/features/usa-vs-iran-france-98-most-politically-charged-game-world-cup-history

Botter, J. (2018, October 7). Khabib Nurmagomedov brought his best vs. Conor McGregor; Then we saw his worst. Bleacher Report. https://bleacherreport.com/articles/2799490-khabib-nurmagomedov-brought-his-best-vs-conor-mcgregor-then-we-sawhis-worst

Boston Globe. (2020, September 24). Racist comments by UFC fighter GOES UNREBUKED, Causes stir - The Boston Globe. BostonGlobe.com. Retrieved September 17, 2021, from https://www.bostonglobe.com/2020/09/24/sports/racist-comments-byufc-fighter-goes-unrebuked-causes-stir/.

Bourdieu, P. (1978). Sport and social class. Information (International Social Science Council), 17(6), 819-840. https://doi.org/10.1177/053901847801700603

BBC News. (2018, October 8). Khabib Nurmagomedov v Conor McGregor: Dagestan celebrates win. https://www.bbc.com/news/worldeurope-45782513

Buruma, I., \& Margalit, A. (2005). Occidentalism: The West in the eyes of its enemies (Reprint ed.). Penguin Books.

Business Insider. (2018a, October 11). Vladimir Putin told Khabib Nurmagomedov's father to cut him some slack after he incited a riot at UFC 229. https://www.businessinsider.in/Vladimir-Putin-told-Khabib-Nurmagomedovs-father-to-cut-him-some-slackafter-he-incited-a-riot-at-UFC-229/articleshow/66164956.cms 
Business Insider. (2018b, October 8). Khabib Nurmagomedov taunts Conor McGregor by calling him "slow" in his first Instagram since victory. Business Insider. https://www.businessinsider.in/sports/khabib-nurmagomedov-taunts-conor-mcgregor-by-calling-him-slow-in-his-first-instagram-since-victory/articleshow/66124172.cms

Business Insider. (2019, September 8). Conor McGregor calls for a rematch in Moscow after Khabib Nurmagomedov retains UFC lightweight title against Dustin Poirier. Business Insider Nederland. https://www.businessinsider.nl/conor-mcgregor-khabib-nurmagomedov-rematch-moscow-2019-9?international=true\&r=US

Considine, C. (2017). The Racialization of Islam in the United States: Islamophobia, hate crimes, and “Flying while Brown." Religions, 8(9), 165. https://doi.org/10.3390/rel8090165

Corbin, J. M., \& Strauss, A. (2008). Basics of Qualitative Research: Techniques and Procedures for Developing Grounded Theory (3rd ed.). SAGE Publications, Inc.

Creswell, J.W. (1998). Qualitative Inquiry and Research Design: Choosing among Five Traditions. SAGE.

Dębnicki, K. (2016). The Pakistani Identity Constructed in Reaction to the Outside World. Politeja, 13(40), 349-371. https://doi.org/10.12797/politeja.13.2016.40.22

Dyreson, M. (2010). Reading American readings of Beijing 2008. The International Journal of the History of Sport, 27(14-15), 2510-2529. https://doi.org/10.1080/09523367.2010.504588

Dyreson, M. (2012). World Harmony or an athletic 'Clash of Civilizations'? The Beijing Olympic spectacle, BMX bicycles and the American contours of globalisation. The International Journal of the History of Sport, 29(9), 1231-1242. https://doi.org/10.1080/09523367.2012.692249

Elo, S., \& Kyngäs, H. (2008). The qualitative content analysis process. Journal of Advanced Nursing, 62(1), 107-115. https://doi.org/10.1111/j.1365-2648.2007.04569.x

ESPN. (2020, January 14). Conor McGregor on drinking during Khabib camp, \$80M payday vs. Cowboy, boxing future. ESPN.Com. https://www.espn.com/mma/story/_id/28471345/conor-mcgregor-drinking-khabib-camp-80m-payday-vs-cowboy-boxingfuture

Fairclough, N. (1989). Language and power. Longman.

Fairclough, N. (1995). Critical discourse analysis. Longman.

Feagin, J. R., \& Feagin, C. B. (2009). Theoretical perspectives in race and ethnic relations. In C. A. Gallager (Ed.), Rethinking the color line: Readings in race and ethnicity. (pp. 22-32). McGraw Hill.

Feagin, J. R. (2001). Social Justice and sociology: Agendas for the twenty-first century: Presidential address. American Sociological Review, 66(1), 1. https://doi.org/10.2307/2657391

Feagin, J. R., \& Ducey, K. (2017). Elite White Men Ruling: Who, What, When, Where, and How (1st ed.). Routledge.

Gentzkow, M. A., \& Shapiro, J. M. (2004). Media, Education and Anti-Americanism in the Muslim World. Journal of Economic Perspectives, 18(3), 117-133. https://doi.org/10.1257/0895330042162313

Gill, R. D. (2004). Orientalism and Occidentalism: Is the Mistranslation of Culture Inevitable? (Second Printing ed.). Paraverse Press.

Gordon, M. M. (1964). Assimilation in American Life: The Role of Race, Religion and National Origins (1st ed.). Oxford University Press.

Harkness, G. (2012). Spring forward: Female Muslim soccer players in Iraqi Kurdistan. Soccer \& Society, 13(5-6), 720-738. https://doi.org/10.1080/14660970.2012.730775

Haynes, J. (2017). Donald Trump, “Judeo-Christian Values," and the “Clash of Civilizations.” The Review of Faith \& International Affairs, 15(3), 66-75. https://doi.org/10.1080/15570274.2017.1354463

Haynes, J. (2019). Introduction: The "Clash of Civilizations" and relations between the West and the Muslim World. The Review of Faith \& International Affairs, 17(1), 1-10. https://doi.org/10.1080/15570274.2019.1570756

History of UFC. UFC. (2021, July 23). Retrieved September 17, 2021, from https://www.ufc.com/history-ufc.

Huntington, S. P. (1993). The clash of civilizations? Foreign Affairs, 72(3), 22-49. https://doi.org/10.2307/20045621 
Huntington, S.P. (1996). The clash of civilizations and the remaking of world order. Simon and Schuster.

Hussain, U. \& Cunningham, G. B. (2020). “These are 'Our' sports”: Kabaddi and Kho-Kho women athletes from the Islamic Republic of Pakistan. International Review for the Sociology of Sport, 1-19. Advance online publication. https://doi.org/10.1177/1012690220968111

Irish Examiner. (2018, Oct 05). The UFC call him Russian but, like his hated rival, Khabib is much more complicated. https://www.irishexaminer.com/sport/arid-30873697.html

Lewis, B. (1990). The Roots of Muslim Rage. The Atlantic, 1, 47-60.

Malcolm, D., Bairner, A., \& Curry, G. (2010). “Woolmergate”: Cricket and the representation of Islam and Muslims in the British Press. Journal of Sport and Social Issues, 34(2), 215-235. https://doi.org/10.1177/0193723510367768

Moher, D., Liberati, A., Tetzlaff, J., \& Altman, D. G. (2009). Preferred reporting items for systematic reviews and meta-analyses: The PRISMA statement. PLoS Medicine, 6(7), e1000097. https://doi.org/10.1371/journal.pmed.1000097

Nakamura, Y. (2002). Beyond the Hijab: Female Muslims and Physical Activity. Women in Sport and Physical Activity Journal, 11(2), 21-48. https://doi.org/10.1123/wspaj.11.2.21

National Public Radio. (2018). More Than 3,100 migrants died crossing Mediterranean in 2017. National Public Radio. https://www.npr.org/sections/thetwo-way/2018/01/06/576223035/more-than-3-100-migrants-died-crossing-mediterraneanin-2017

Newman, J. I. (2014). Sport Without Management. Journal of Sport Management, 28(6), 603-615. https://doi.org/10.1123/jsm.2012-0159

Pugmire, L (2018). Faith comes before fists for Khabib Nurmagomedov. LA Times https://www.latimes.com/sports/boxing/la-spufc-khabib-20180405-story.html (accessed 11 June 2020)

Ratna, A. \& Samie, S.F. (2017). Introduction: sport, race and gender: The politics of ethnic'other' girls and women. In Ratna, A. \& S.F. Samie (Eds.), Sport, race and gender - the politics of ethnic 'Other' girls and women (pp. 1-9). Routledge.

Reuters. (2018, October 7). Brawls overshadow Khabib's UFC title win over McGregor. Reuters. https://www.reuters.com/article/usmma-ufc-ufc229-brawls/brawls-overshadow-khabibs-ufc-title-win-over-mcgregor-idUSKCN1MH09P

Roose, J. M., \& Turner, B. S. (2019). Islamophobia, science and the advocacy concept. Society, 56(3), $210-221$. https://doi.org/10.1007/s12115-019-00357-6

Said, E. W. (1978). Orientalism. Pantheon Books.

Samie, S. F. (2013). Hetero-sexy self/body work and basketball: The invisible sporting women of British Pakistani Muslim heritage. South Asian Popular Culture, 11(3), 257-270. https://doi.org/10.1080/14746689.2013.820480

Said, E. (1992). Peace and the Middle East. Journal of Communication Inquiry, 16(1), 5-19. https://doi.org/10.1177/019685999201600101

Samie, S.F. (2017). De/colonizing 'sporting Muslim women': Post-colonial feminist reflections on the dominant portrayal of sporting Muslim women in academic research, public forums and mediated representations. In A. Ratna \& S.F. Samie (Eds.), Sport, race and gender - the politics of ethnic 'Other' girls and women (pp. 35-62). Routledge.

Samie, S. F., \& Sehlikoglu, S. (2014). Strange, incompetent and out-of-place. Feminist Media Studies, 15(3), 363-381. https://doi.org/10.1080/14680777.2014.947522

Samiei, M. (2010). Neo-Orientalism? The relationship between the West and Islam in our globalised world. Third World Quarterly, 31(7), 1145-1160. https://doi.org/10.1080/01436597.2010.518749

Sen, R. (2015). Nation at play: A history of sport in India. Columbia University Press.

Shahi, D. (2017). Understanding post-9/11 Afghanistan: A critical insight into Huntington's civilizational approach (E-IR Open Access). EInternational Relations.

Singer, J. N., Shaw, S., Hoeber, L., Walker, N., Agyemang, K. J. A., \& Rich, K. (2019). Critical conversations about qualitative research in sport management. Journal of Sport Management, 33(1), 50-63. https://doi.org/10.1123/jsm.2018-0085 
South China Morning Post. (2018). UFC: Khabib and Vladimir Putin throw shade at Conor McGregor as Russian President praises chokehold. South China Morning Post. https://www.scmp.com/sport/martial-arts/mixed-martial-arts/article/3027058/ufc-khabiband-vladimir-putin-throw-shade

The Express Tribune. (2018). McGregor can pass racist and Islamophobic insults, but Nurmagomedov can't react to it? The Express Tribune.https://tribune.com.pk/article/72808/mcgregor-can-pass-racist-and-islamophobic-insults-but-nurmagomedov-cantreact-to-it (accessed 25 July 2020)

The New York Times. (2018). Khabib Nurmagomedov could face fine and suspension after brawl at UFC 229. The New York Times. https://www.nytimes.com/2018/10/07/sports/mcgregor-khabib-ufc-229.html (accessed 27 October 2020)

Toffoletti, K., \& Palmer, C. (2016). New approaches for studies of Muslim women and sport. International Review for the Sociology of Sport, 52(2), 146-163. https://doi.org/10.1177/1012690215589326

Turkish Radio and Television Corporation World. (2018). Criticism of Khabib smacks of racism. TRT World. https://www.trtworld.com/opinion/criticism-of-khabib-smacks-of-racism-20718

Turkish Radio and Television Corporation World (2020) Khabib: An unabashedly Muslim champion in an Islamophobic world. TRT World. https://www.trtworld.com/opinion/khabib-an-unabashedly-muslim-champion-in-an-islamophobic-world-40866

UFC. (2019). UFC 229 Generates Record Sums For Las Vegas. UFC. https://www.ufc.com/news/ufc-229-generates-record-sums-lasvegas

USA Today. (2019). Conor McGregor tweets, deletes personal attack on Khabib Nurmagomedov's wife. USA Today.: https://www.usatoday.com/story/sports/mma/2019/04/02/conor-mcgregor-tweets-deletes-personal-attack-on-khabib-nurmagomedovswife/39292123/ (accessed 10 June 2020)

Venn, C. (2000). Occidentalism: Modernity and subjectivity. Sage Publications Ltd.

Vestnik Kavkaza. (2018, December 19). Khabib Nurmagomedov: They call me Russian in the west. Retrieved September 17, 2021, from https://vestnikkavkaza.net/news/Khabib-Nurmagomedov-they-call-me-Russian-in-the-West.html.

Vorländer, H., Herold, M., \& Schäller, S. (2019). PEGIDA and new right-wing populism in Germany (New Perspectives in German Political Studies) (Softcover reprint of the original 1st ed. 2018 ed.). Palgrave Macmillan.

Zidan, K. (2019). Chechen Expansion: How Ramzan Kadyrov cozying up to UFC champ Khabib Nurmagomedov is a tool for geopolitical diplomacy. Bloody Elbow. https://www.bloodyelbow.com/2019/6/13/18662837/chechen-expansion-ramzan-kadyrov-ufcchamp-khabib-nurmagomedov-politics-karim-zidan-mma-feature (accessed 05 May 2020) 